
\title{
28 Research Suare \\ Effectiveness of the Classification for the Phosphorus Use Efficiency Traits at the Seedling Stage in Lentil
}

Research article

Keywords:

Posted Date: February 3rd, 2021

DOI: https://doi.org/10.21203/rs.3.rs-117870/v2

License: (c) (1) This work is licensed under a Creative Commons Attribution 4.0 International License.

Read Full License 


\section{Abstract}

The authors have requested that this preprint be withdrawn due to erroneous posting.

\section{Full Text}

The authors have withdrawn this preprint from Research Square. 